\title{
Inventing Law in Local Settings: Rethinking Popular Legal Culture
}

\author{
Barbara Yngvesson†
}

[T]erms like popular culture or popular art . . . assume the existence of two kinds of culture, high and popular, which are so different that they cannot be compared, thus positing an initial dichotomy which then shapes all subsequent analysis. ${ }^{1}$

\section{INTRODUCTION}

Like the notion of "popular culture," popular legal culture implies the existence of an official culture of law distinct from everyday legal practices and understandings. Ethnographic studies of law, in the United States and cross-culturally, underscore the significance of this distinction, which becomes most apparent in colonial contexts where a new state system is imposed on traditional legal forms. ${ }^{2}$ Yet equally striking differences have been noted in the industrialized West between an official rule of law codified in formal statutes, dominated by a professional elite and symbolized in a national system of courts, on the one hand, and unofficial systems in which informal agreement, various forms of self-help, gossip, avoidance, and "lumping it" are customary practice, on the other. ${ }^{3}$

While these distinctions are familiar, it is less clear how to explain the connection of the "official" to the "popular," the extent to which we are describing what is clearly a "plural" legal order or variations on a "parent social speech," and the degree to which the "popular" is subtly constituted, and ultimately, transformed by the "official" (or vice versa), even in situations where there is no evident imposition of a particular order of

† Professor of Anthropology, Hampshire College.

1. H. Gans, Popular Culture and High Culture 10 (1974).

2. See, e.g., J. Collier, Law and Social Change in Zinacantan (1973); The Imposition of LAw (S. Burman \& B. Harrel-Bond eds. 1979); S. MOORE, Social Facts and Fabrications: "Customary" Law on Kilmanjaro, 1880-1980 (1986). An overview of literature on legal pluralism which addresses the problems involved in distinguishing state from non-state law is provided in Merry, Legal Pluralism, 22 Law \& Soc'y Rev. 869 (1988).

3. See The Disputing Process: Law in Ten Societies (L. Nader \& H. Todd, Jr. eds. 1978); Engel, Legal Pluralism in an American Community: Perspectives on a Civil Trial Court, AM. B. Found. RES. J. 425 (1980); Felstiner, Influences of Social Organization on Dispute Processing, 9 LAW \& Soc'y REv. 63 (1974); see also Merry, supra note 2, at 872-74.

4. Gordon, Critical Legal Histories, 36 Stan. L. Rev. 90 (1984). 
law. Thus while the notion of popular legal culture appears in one sense self-evident, it is an inherently problematic concept, implying the existence of separate spheres of law rather than providing a more complex analysis of the ways legal culture is produced, and popular understandings of the law shaped.

In this essay I move away from the notion of "popular" legal culture to argue that law is both shaped in local terms and produced by relations of power through which particular configurations of law (as "high," as "low," as "central," as "peripheral," as "official" or as "popular") are defined. This requires an analysis of legal culture that draws on work in interpretive anthropology and literature in political and legal theory. These two literatures have distinct, but ultimately connected positions on how legal culture is to be understood.

Interpretive literature in anthropology locates culture in the "contradictory, multistranded, and complex assumptions, actions, memories, and talk of people who communicate with one another and who are alert to commonalities in the conduct of their lives."' Anthropologists writing in this tradition interpret legal culture as a local phenomenon, shaped by local knowledge and practice, through which symbols such as "law" or "court," understandings of "rights" and "wrongs," and concepts of "crime," of "normal trouble" or of complaining and dispute take on particular, locally relevant meanings. In an interpretive account, legal culture not only differs in different contexts, but law is "invented," negotiated, or "made" in local settings. ${ }^{6}$ This approach to legal culture suggests that it is only as "popular" culture, as local "common" sense that informs the ways people view and act upon the world, that any sense can be made of law. Further, interpretivists understand the production of law as an ongoing process, dialectically linked to the production of community, which is both a vehicle for and an outcome of the invention of law. ${ }^{7}$

While interpretivist accounts of legal culture illuminate the diversity of law by focusing on local production of meaning, they are less attentive to the centrality of power in the meaning-making process; questions of how the kind of interpretation produced is shaped by actors who are endowed with particular social characteristics are unexplored. When power is

5. M. Rosaldo, Knowledge and Passion: Ilongot Notions of Self and Social Life 26 (1980).

6. For a general discussion of this approach, see C. GeERTZ, LOCAL KNOwLEDGE (1983) and R. WAGNER, THE INVENTION OF Culture (1981). Empirical studies of the making of legal culture include Greenhouse, Courting Difference: Issues of Interpretation and Comparison in the Study of Legal Ideologies, 22 LAw \& Soc'y Rev. 687 (1988); Harrington \& Merry, Ideological Production: The Making of Community Mediation, 22 LAw \& Soc'y REv. 709 (1988); and Yngvesson, Making Law at the Doorway: The Clerk, the Court and the Construction of Community in a New England Town, 22 LAw \& Soc'Y REv. 409 (1988).

7. This formulation builds on Giddens' notion of "duality of structure" in which structure and agency are understood as mutually dependent: structure is both the medium and the outcome of agency. See A. Giddens, Central Problems in Social. Theory 69 (1979). 
foregrounded, an explanation of popular legal culture must take into account the unequal distribution of the capacity to contrive reality, and specifically what Bourdieu terms the "force of law" as a constitutive dimension in modern society. ${ }^{8}$ In this account, law creates the social world by "naming" it; legal professionals are empowered by their capacity to reveal rights and define wrongs, to construct the meaning of everyday events (as just or unjust, as crime or normal trouble, as private nuisance or public grievance) and thus to shape cultural understandings of fairness, of justice, and of morality. ${ }^{2}$ De Tocqueville's insight that in America "the spirit of the law . . . infiltrates through society right down to the lowest ranks, till finally the whole people have contracted some of the ways and tastes of a magistrate"10 suggests the dimensions of this empowerment and the hegemony of the culture of law:

In the United States the lawyers constitute a power which is little dreaded and hardly noticed; it has no banner of its own; it adapts itself flexibly to the exigencies of the moment and lets itself be carried along unresistingly by every movement of the body social; but it enwraps the whole of society, penetrating each component class and constantly working in secret upon its unconscious patient, till in the end it has molded it to its desire. ${ }^{11}$

This familiar portrayal of law as a pervasive cultural force in American society, shaping our most unquestioned assumptions about self and the relationship of self to other, echoes themes in the historical and contemporary literature on legal culture, and forms the basis for current reform movements aimed at displacing the centrality of law.

Thus, for example, studies of the earliest Puritan settlements suggest that in these seventeenth century communities there was "no room for a communal ideal . . . so constructed as not to include [the magistrates] and the justice they administered."12 With the professionalization of law in the

8. Bourdieu, The Force of Law: Toward a Sociology of the Juridical Field, 38 Hastincs L.J. 2292-94 (1987).

9. See id.; see also Mather \& Yngvesson, Language, Audience, and the Transformation of Disputes, 15 LAW \& Soc'y REv. 775, 783-97 (1980-81). In a related argument, Robert Gordon suggests that "in practice, it is just about impossible to describe any set of 'basic' social practices without describing the legal relations among the people involved-legal relations that don't simply condition how the people relate to each other but to an important extent define the constitutive terms of the relationship, relations such as lord and peasant, master and slave, employer and employee, ratepayer and utility, and taxpayer and municipality," Gordon, supra note 4, at 103; see also Sarat \& Felstiner, Law and Strategy in the Divorce Lawyer's Office, 20 LAw \& Soc'y REv. 93 (1986); Sugarman, Law, Economy and the State in England, 1750-1914: Some Major Issues, in LEGALITY, IDEOLOGY AND THE STATE 213 (D. Sugarman ed. 1983); Trubek, Where the Action Is: Critical Legal Studies and Empiricism, 36 Stan. L. REv. 575 (1984).

10. 1 A. DE Tocoueville, Democracy in America 248 (G. Lawrence trans. 1966) (13th ed. 1850).

11. Id.

12. Black, Community and Law in Seventeenth Century Massachusetts, 90 YALE L.J. 241 (1980); see also G. Haskins, Law and Authority in Early MassachusetTs (1960); D. Konig, 
eighteenth and nineteenth centuries, and particularly with the development of a self-conscious legal elite, legal discourse became increasingly central in a commercial society dependent on lawyers for its transactions, and ultimately (as these transactions became a major form of social and economic exchange) on the law itself to shape a "common" sense of order in society at large. ${ }^{13}$ Today, the ideology of neighborhood justice is directed at reshaping this common sense by empowering local communities in ways that decrease their dependence on law.

Emphasis on the constitutive role of law and on the political importance of fostering non-professional alternatives to law, through which local values can be supported and a local sense of justice nurtured, suggests a uniformity to legal culture that is challenged by recent studies of American communities where law is said to have no place. In these communities, the legal system stands "outside the community of meaning" for established local residents, ${ }^{14}$ and the aggressive assertion of rights in court is associated with the behavior of newcomers unfamiliar with traditional understandings and without access to traditional (non-legal) methods of social control. ${ }^{15}$ Other studies suggest that while law may have a central place, it is used in non-conventional ways. In a culture dominated by a liberal legal ideology of rights, there are many ways in which "rights" can be used and understood. Similarly, while courts are defined and avoided by many as the domain of the greedy, for others they serve as key arenas for forging particular local visions of moral virtue and social order. ${ }^{16}$

This research suggests that an explanation of legal culture requires attention both to what is distinct about local practice, as well as to the ways that "the local" is continuous with (and informed by) official legal ideology. This, in turn, requires an approach to legal culture that is dynamic:

Law and Society in Puritan Massachusetts: Essex County 1629-1692 (1979); J. SMrth, Colonial Justice in Western Massachusetts (1639-1702): The Pynchon Court Record (1961).

13. See D. Provine, Judging Credentials: Nonlawyer Judges and the Politics of Professionalism 1-23 (1986); see also M. Horwitz, The Transformation of american Law 1780-1860 (1977); Botein, The Legal Profession in Colonial North America, in LAWYERS IN EARLY MOdern Europe AND AMerica 129 (W. Priest ed. 1981); Murrin, The Legal Transformation: The Bench and Bar of Eighteenth-Century Massachusetts, in Colonial AmeriCa 415 (S. Katz ed. 1971); Gawalt, Sources of Anti-Lawyer Sentiment in Massachusetts, 1740-1840, 14 AM. J. LEGAL HisT. 283 (1970). For a discussion of the persistence of anti-legal values in commercial society, see J. Auerbach, Justice Without Law? (1983).

14. Greenhouse, supra note 6 , at 704 .

15. See Engel, The Oven-Bird's Song: Insiders, Outsiders and Personal Injuries in an American Community, 18 LAw \& Soc'Y REv. 551, 570 (1984). Engel describes a situation in which established residents in Sander County, the rural farming community where his study was carried out, sanctioned "newcomers" or "outsiders" (residents associated with the introduction of manufacturing plants in the county) for bringing personal injury suits against established citizens. At the same time, he argues that recourse to the legal system was approved when it was directed against newcomers. As this suggests, the "community of meaning" to which the legal system is "external" shifts with the user.

16. See Merry, Concepts of Law and Justice Among Working Class Americans: Ideology as Culture, 9 LeGal Stud. F. 59 (1985); Yngvesson, supra note 6. 
"not an impermeable 'official culture' imposing its criteria on 'popular culture,' but cultural exchange, conducted inside the king's rules."17

The argument of this essay is developed from this perspective. Drawing on ethnographic and historical research, I consider the ways that local legal practice reproduces official understandings while challenging these with claims and actions that reflect different assumptions about morality, about community, and about justice. From this perspective, "the spirit of law," while embodying the concerns of a powerful and dominant professional elite, is not simply invented at the top but is transformed, challenged, and reinvented in local practices that produce a plural legal culture in contemporary America. Recognition of plurality (or difference) does not eclipse the reality of pervasive cultural understandings and values however. Hegemony ${ }^{18}$ assumes plurality: "[It] does not just passively exist as a form of dominance. It has continually to be renewed, recreated, defended, and modified. It is also continually resisted, limited, altered, challenged by pressures not at all its own."18 The hegemony of a liberal legal ideology of rights is both reinforced and undermined by local struggles. The interpretation of key symbols ("rights," "wrongs," "community," "court") is contested, while the dominance of a particular structure of differences in society ${ }^{20}$ is left unquestioned. Only by viewing legal culture in this dynamic way can we explain popular consciousness as a force contributing to the production of legal order rather than as simply an anomaly or a pocket of consciousness "outside" of law, irrelevant to its maintenance and transformation.

In what follows, I examine the invention of law through contests over the interpretation of cultural symbols in two types of local settings: county courts and neighborhood justice centers. In both, I focus on the relations of legal and other officials with local publics or audiences in the management of problems of neighborhood and family order. The analysis points to the ways in which local empowerment and official control are interwoven, and to the ways in which resistance (and creativity) may emerge from interdependence (and domination). Analysis of this dynamic suggests the importance of a theoretical perspective in which the production of law is explained in the context of ongoing relations of inequality, of struggle, and of cooperation, while the maintenance of these relations is explained in the context of law.

17. N. Davis, Fiction in the ARchives: Pardon Tales and Their Tellers in SixTEenth-Century France 112 (1987).

18. Raymond Williams defines hegemony as "a complex interlocking of political, social, and cultural forces" that sustains particular forms of inequality and domination. R. WILliamS, MaRXISM AND LITERATURE 112 (1977).

19. Id.

20. This structure of differences includes ranked "public" and "private" spheres; the distinction of "law" and "community," and the understanding that community is constructed by law; and the notion of persons as constituted by "rights," which define them as separate individuals. 


\section{Legal Gulture and local Gourts}

Popular legal culture in contemporary America consists of a variety of dissimilar subcultures: relatively insulated symbolic systems of ethnic groups, such as the Chinese, in which harmony and group responsibility are central, and order is maintained by non-adversarial procedures such as moral persuasion rather than open confrontation or litigation; ${ }^{21}$ a mainstream culture of liberal legalism shaped by an emphasis on individual rights, characterized by sensitivity to violations of rights, and associated with court use as a vehicle for claims by individuals on one another,;2 rural practices in farming and ranching areas in which values of selfsufficiency, personal responsibility, and neighborly cooperation produce various informal social control practices including gossip, self-help, and "lumping it," rather than litigation; ${ }^{23}$ avoidance as a pattern of conflict management among neighbors and intimates in working- and middle-class American neighborhoods, where social relations are shaped by values of autonomy and self-mastery, and court use is associated with a fall from respectability, ${ }^{24}$ and the frequent use of police, courts, and other state or local agencies as vehicles for self-help in local political battles and as a means for shaping moral order among urban low-income populations. ${ }^{25}$

While courts are widely associated today with the aggressive pursuit of rights-with people who are "very greedy," "quick to sue," and "troublesome"28 - and thus rejected by groups whose self-image is defined by the capacity to transcend conflict or to "work things out" in private, ${ }^{27}$ they

21. See Doo, Dispute Settlement in Chinese-American Communities, 21 AM. J. CoMP. L. 627, 636-38 (1973). Doo's study examines mediation procedures used by Chinese-Americans, discussing the roots of these procedures in traditional values of Chinese society, and their maintenance in a hostile United States environment. In this environment, Chinese immigrants "turn[ed] inward to Chinese people, institutions and values with which they were familiar for security and isolation." Id. at 629.

22. See S. Scheingold, The Polttics of Rights: Lawyers, Public Policy, and Political Change (1974) (provides general discussion of liberal legal ideology of rights, and its links to values of individualism, private property, and market economy, in the United States); Merry, Everyday Understandings of the Law in Working-Class America, 13 AM. ETHNoLoGIST 253 (1986) (discussing manifestation of this ideology in one working class community).

23. See Ellickson, Of Coase and Cattle: Dispute Resolution Among Neighbors in Shasta County, 38 STAN. L. REV. 623 (1986); Engel, supra note 15. Engel and Ellickson both discuss the avoidance of formal law among people who define themselves as part of the same, informally interacting, social group, but note as well the recourse to law when this system breaks down, or when "outsiders" are involved in a local conflict.

24. See Baumgartner, Social Contral in Suburbia, in 2 Toward a General. Theory of SoCIAL Control 79 (D. Black ed. 1984); Greenhouse, supra note 6. Merry and Silbey, and Greenhouse describe middle and working-class communities in the eastern and southern United States where "virtue" is incompatible with court use; Merry \& Silbey, What Do Plaintiffs Want? Reexamining the Concept of Dispute, 9 JUST. SYs. J. 151 (1984); Baumgartner, by contrast, focuses on the alienation of middle class residents of a New Haven suburb, and on forms of social and physical compartmentalization which allow people to walk away from or avoid conflict.

25. See Merry, Going to Court: Strategies of Dispute Management in an American Urban Neighborhood, 13 LAw \& Soc'y REv. 891 (1979); Merry \& Silbey, supra note 24; Yngvesson, supra note 6.

26. Engel, supra note 15 , at 553-58, 559; Merry \& Silbey, supra note 24 .

27. See C. Greenhouse, Praying for Justice: Faith, Order, and Community in an 
nevertheless play a complex but central role in many localities as arenas where community is created and notions of self and other defined. More established citizens may use the court as a vehicle for controlling newcomers, "outsiders," and other marginal persons and groups whose presence threatens a customary way of life. ${ }^{28}$ Alternatively, courts may be used by marginal groups to shape a moral order of their own, and as sites for resistance to established visions of community order and of law. ${ }^{29}$ Even among groups for which the court stands "outside the community of meaning," it may nevertheless act as a central symbol, "mark[ing] . . . the convergence of multiple lines of differentiation: between past and present, insiders and outsiders, harmony and trouble . . ."30 Like the fair or the marketplace in seventeenth and eighteenth century European towns, the local court is "the epitome of local identity (often indeed it is what defined a place as more significant than surrounding communities) and the unsettling of that identity by the trade and traffic of goods from elsewhere."231

The connection of local courts to local identity and their use as arenas where images of community are contested and forged have deep roots in colonial legal culture. Studies of county sessions courts in the seventeenth and eighteenth centuries suggest that these institutions played a key role in shaping moral order in a society built on the ideal concept of saints in covenant with God and "knit together" in a "bond of love,"32 but with a population that was religiously, economically, and culturally diverse. In most towns, only a minority of settlers were church members, ${ }^{33}$ while in others, settlers were drawn from areas of England with different economic and political traditions. ${ }^{34}$ In addition, there was a great deal of movement within and between towns, affected by land availability, religious tensions, and economic pressures of various kinds, and towns were repeatedly split by religious and other forms of political conflict. ${ }^{35}$

AMERICAN Town (1986); Doo, supra note 21; Merry \& Silbey, supra note 24.

28. See Engel, supra note 15, at 551-82; Greenhouse, supra note 6.

29. See Yngvesson, supra note 6.

30. Greenhouse, supra note 6 , at 689 .

31. P. Stallybrass \& A. White, The Politics and Poetics of Transgression 27 (1986).

32. Hall, Understanding the Puritans, in Colonial AMERICA, supra note 13, at 48 (quoting John Winthrop).

33. P. Miller, The New England Mind: From Colony to Province 114 (1953). Miller describes seventeenth century communities as a series of concentric circles, with "the church" at the center, "the congregation" (or half-way members) beyond this, and on the outer circumference, the town, in which full communicants were a "dwindling minority" by the end of the century.

34. The population of Hingham, Massachusetts, for example, contained both West Country farmers who "took to the new Puritan ethos lightly" and settlers from East Anglia, an area known for its weaving industry, who came to the new world, not as individual settlers seeking to increase their estates and profits, but "as members of a conscious community of God's people." Waters, Hingham, Massachusetts, 1631-1661: An East Anglian Oligarchy in the New World, in Colonial AmERICA, supra note 13, at 56. Similar differences are described for Salem and ather towns in Essex County. See D. KoniG, supra note 12 , at 69-74.

35. See P. Boyer \& S. Nissenbaum, Salem Possessed: The Social Origins of Witchcraft (1974); K. Lockridge, A New England Town: The First Hundred Years (1970); Demos, 
This meant that in spite of a communal ideal centered on the discipline of sainthood and "holy watching,"36 the experience and practice of community was predominantly conflictual, and the county courts, like the church, the selectmen, and other town committees, became key arenas where battles over local identity were played out, although often in coded form. Ethnic and other forms of inter-group conflict might appear before the selectmen or in court as requests for clarification of property rights, ${ }^{37}$ as demands for payment of taxes, or as complaints of lying or cheating. ${ }^{38}$ In this way, routine petitions of local residents became vehicles for influencing political contests, for creating rights and defining obligations, and for shaping notions of justice.

A study of seventeenth century town records in Dedham and Watertown reveals that the routine management of claims and presentments brought to the selectmen (regarding property rights, care of the poor, or the guilt of men whose livestock had damaged crops) transformed this group into "the most active and often the most creative political element in these towns prior to the late seventeenth century." ${ }^{39}$ Studies of county court dockets suggest that lay judges were equally significant in transforming private claims into a vision of moral order. But these studies also point to the empowerment of complainants and others in this process, in courts that depended on the involvement of a local public for its work. ${ }^{40}$

County courts were familiar arenas in the seventeenth and eighteenth centuries, places to which "the small farmer or artisan would turn if he wished to replevy his cows or to collect a bill, and that turned upon him if his hogs were unringed or if he put his garbage in the street." ${ }^{\text {"41 }}$ Research on colonial culture suggests that this familiarity was linked to a paternalistic society in which the magistrates who sat in county courts (like the English gentry from which some of them derived) were "revered . . . and looked to for protection." ${ }^{22}$ But it derived as well from the conditions of magisterial authority, since the governance role of the magistrates, like that of selectmen, depended upon the willingness of private parties to come to them with complaints. Thus magistrates are described as "creat[ing] . . . inducements and incentives" to bring petitioners and com-

Notes on Life in Plymouth Colony, in Colonial AMERICA, supra note 13, at 69; Lockridge \& Kreider, The Evolution of Massachusetts Town Government, 1640 to 1740, in id. at 203.

36. Walzer, Puritanism as a Revolutionary Ideology, 3 Hist. \& TheORY 59, 79-82 (1960).

37. See D. Konig, supra note 12, at 55-56.

38. See id. at 70-72.

39. Lockridge \& Kreider, in Colonial AMerica, supra note 13, at 210.

40. See Jones, The Transformation of the Law of Poverty in Eighteenth Century Massachusetts, in LAw in Colonial MassaChusetTs, 1630-1800 (F. Allis, Jr. ed. 1984); Hartog, The Public Law of a County Court; Judicial Government in Eighteenth Century Massachusetts, 20 AM. J. LEGAL HisT. 282 (1976).

41. Goebel, Jr., King's Law and Local Custom in Seventeenth Century New England, in Essays in the History of Early American Law 88 (D. Flaherty ed. 1969).

42. Black, supra note 12, at 241; See Hay, Property, Authority and the Criminal Law, in ALbion's Fatal Tree: Crime and Society in Eighteenth-Century England 47 (1975). 
plainants to court, ${ }^{43}$ encouraging the use of the court as a weapon (as in cases of harassment or minor assault charges), charging defendants for the cost of their trials, and agreeing to rehear cases in which the parties continued to struggle for decades over the same matters. ${ }^{44}$

At the Salem court, for example, the tense relations between Englishmen and French-speaking settlers from the Isle of Jersey were fought out in complaints of abuse of authority, of theft, and of cheating in the 1670's and 1680's. While these charges were a means of harassment, court use contributed as well to the way members of these groups perceived each other. The most prominent of the Jerseymen, a wealthy French-speaking merchant named Philip English, contributed to the reputation of these settlers as greedy and self-interested by frequent use of the court on his own behalf. But the court was also used by Englishmen to defame Philip English and other Jerseymen with accusations of theft and charges that English, who was a constable, failed to collect taxes from his own people. ${ }^{45}$

These exchanges were one aspect of an ongoing process in which diverse factions in seventeenth century Salem struggled for dominance through court battles in which particular charges (theft, abuse of authority) became symbolic of competing forms of community identity. By encouraging the use of the court for battles of this kind, seventeenth century magistrates shaped a tradition in which the political and legal roles of the court were interwoven, and in which the magistrates themselves came to play an increasingly prominent role in defining the nature of "community" in local settlements.

Historical accounts of this process tell us a good deal about local battles, and a considerable amount about the coordinating function of the court, ${ }^{46}$ but provide little insight into the ways that contests over community ideology, or over other symbols such as "rights," were conducted in court hearings. There is, however, some evidence that the tension between selectmen and magistrates as key figures in shaping local morality was advantageous to less powerful parties, who used the court to sharpen divisions in local governance. Thus Sarah Moor of Rowley brought a complaint to the Essex County Sessions Court in 1767, arguing that a decision by the selectmen to take her children from her and bind them into service with another family was neither in their interests nor in hers, and charging the selectmen with cruelty. Her petition stated that "it was not customary to permit local officials to take illegitimate children away from their mothers when they had a good home." ${ }^{\text {"47 }}$ In granting her petition, the magistrates

\footnotetext{
43. Hartog, supra note 40 , at 318 .

44. See id. at 318-22.

45. D. KonIG, supra note 12 , at 70-72.

46. Id. at 74,88 .

47. See Jones, in Law in Colonial Massachusetts, 1630-1800, supra note 40, at 163 .
} 
supported her construction of the situation, giving maternal rights priority over the economic burden this might place on the town.

In cases such as these, which fell between moral and regulatory order, magistrates and complainants shaped standards of fairness, defined concepts of "right," and forged a legal culture in which the magistracy became a prominent moral force in local communities. ${ }^{48}$ This culture was both "high" and "low." It spoke to the concerns and the "common" sense of a powerful elite, but depended for its construction on the tales and the participation of everyday people: accounts of cheating and conniving by French-speaking Jerseymen and stories such as that of Sarah Moor struggling to keep her two children. The interpretation of these tales in court privileged themes that are familiar today: individual greed versus communal responsibility; individual rights versus community welfare. In this sense, it was the magistrates, an elite group of laymen serving at all levels of colonial justice and governance, who shaped a common legal culture out of local complaints. Their capacity to do this, however, depended on their place in a social order where the "tissue of paternalism" created ties of interdependence between people at the center of society and those at the fringe. These ties provided a cultural basis for trust and a structural underpinning for power. ${ }^{49}$

The professionalization of law and the growth of a powerful and selfconscious legal elite in the eighteenth century led to an increasing stratification of forums and a transformation in the meaning of the county court from an institution that joined law and governance to one that existed largely to separate the spheres of each. ${ }^{50}$ "Magistratical authority" came to be vested in county justices and court clerks, local figures whose legal significance is defined by a professional culture of law that trivializes "lower" courts and those who serve there. ${ }^{51}$

This shift has tended to divide courts into those which handle real law and local courts which do not. Yet, magistrates who are legally marginal become culturally central, contributing both to the production of "community" through law and to the production of a legal order that separates law and community. ${ }^{52}$ Their capacity to do this, however, depends on their connection to local audiences. This connection is increasingly eroded by the legal definition of "real" courts as professional arenas, circum-

48. See id. at 162-64; see also Hartog, supra note 40, at 323.

49. The tension between trust and the coercive power of a small, interconnected elite that controlled the legislative, administrative, and judicial affairs of the colony is a prominent theme in much of the literature on this period. See G. Haskins, supra note 12, at 25-42; see also Haskins, Lay Judges: Magistrates and Justices in Early Massachusetts, in LAW IN ColonIAL MASSACHuSETTS, $1630-1800$, supra note 40 , at 39 ; Black, supra note 12 , at $239-41$; D. Konic, supra note 12 , at 26-34.

50. See Hartog, supra note 40.

51. See C. Harrington, Shadow Justice 20 (1985); McBarnet, Magistrates' Courts and the Ideology of Justice, 8 BRIT. J.L. \& Soc'Y 181, 195 (1981).

52. See generally Yngvesson, supra note 6 . 
scribed by "real" legal rules controlled from within, rather than as popular arenas, responsible to local publics.

In the remainder of this essay, I examine the tension surrounding the practice of "popular" justice in local arenas, focusing on the use of county courts by local citizens to handle issues of moral order and on efforts by the legal profession and others to transform this practice, shifting it from the courts to centers for neighborhood justice. In particular, I focus on the use of an ideology of "popular" or "community" control and a rhetoric of local empowerment to reshape popular legal culture in ways that increase professional control and privilege a meaning of community in which local ties are undermined.

\section{Popular Justice in Professional Arenas}

The transformation of local courts into institutions structured by professional guidelines rather than shaped by local politics has been broadly supported on the basis that the "rough" justice administered there undermines the legal rights of the poor and minorities who make up the bulk of lower court defendants. ${ }^{53} \mathrm{~A}$ more professional institution should be less subject to corruption and less apt to impose local cultural biases in the guise of legal sentences. This should promote "fair" outcomes by insuring proceedings that are procedurally correct and using more generally established standards to judge behavior.

At the same time, the move to centralize court systems disempowers local populations that understand "law" and "legal rights" as fundamental moral rights, and that use the court as a forum for enforcing particular views of moral order. ${ }^{54}$ Legal officials in some county courts find it disempowering because it undermines their role in local governance. For these officials the court fills a moral vacuum created as "families, schools, churches, police-even down to the individual-are in retreat." Others speak of the court as providing "moral sense," a "sense" that includes awareness of a community of interests extending beyond the pursuit of individual legal rights. ${ }^{55}$ Thus, for example, in "Hopewell," the community of Southern Baptists studied by Carol Greenhouse, the judge and the court clerk thought court use symbolic of the disintegration of traditional bonds, and as supplying needed external controls for "isolated individuals or nuclear families living without social resources and without trust." the midwestern farming community described by David Engel, the aggres-

53. See generally Rough Justice: Perspectives on Lower Criminal Courts (J. Robertson ed. 1974).

54. See Merry, supra note 16 , at 67.

55. Statements by Clerk Magistrate and Assistant Clerk Magistrate at a western Massachusetts district court. The names and exact location of the clerks are undisclosed in accordance with the anonymity of the published empirical research. See generally Yngvesson, supra note 6.

56. Greenhouse, supra note 6, at 696. 
sive assertion of rights in court by newcomers was interpreted as "looking for the easy buck," but established residents made regular use of the court for collecting debts in breach of contract cases. In these "morally offensive" matters, the court was crucial. It supported the values of personal obligation and the sanctity of the promise which had been fundamental in a farming community dependent on reciprocal exchange. ${ }^{57}$

Thus, while court users may be thought lacking in virtue by court staff and other more established citizens, ${ }^{58}$ the court itself may be locally perceived as an important moral force, and efforts to undermine local control may be resisted. In Western Massachusetts, the 1978 Court Reorganization $\mathrm{Act}^{59}$ was bitterly resisted by a county with efforts to "lock state workers out of the courthouse." One official referred to the state's action as "rape," and local news media described the courthouse as a "symbol of county government." ${ }^{\text {"60 }}$ Resentment to what was perceived a "takeover" of the courthouse by the state was still experienced and discussed in the early 1980's.

The struggle by local courts to maintain a significant role as moral arbiters in surrounding neighborhoods and communities is matched by the determination of complainants to use the courthouse for moral and political agendas of their own. These complainants come to the court with a range of problems, from the quarrels of parents and children, lovers, neighbors, or other intimates, to conflicts with employers, local companies, landlords and others. For these people, their understanding of "legal rights" involves the right "to control who is on one's property and what happens on one's property . . . [and] rights not to be insulted, harassed, or hit by neighbors or family members without sufficient reason." assumptions structure a broad spectrum of social relations, and also become "an opportunity, a basis for action," as claims or grievances brought to the courthouse. ${ }^{62}$

In many courts, these complaints are viewed as typical "nuisance cases." Handled by the least educated and least prestigious of court officials, they are redefined as non-criminal ("garbage") matters and cursorily dismissed. ${ }^{63}$ For example, in a complaint of "violent harassment" brought by a cook in an eastern Massachusetts restaurant against her former boyfriend, the court clerk stated flatly that "there is no such crime as harassment" and dismissed the matter. The complainant asked in disbe-

57. Engel, supra note 15, at 574-77.

58. See Merry \& Silbey, supra note 24 , at 172.

59. This Act shifted funding for local courts from the county to the state and reorganized the court system into a centralized District Court department presided over by a Chief Justice.

60. The actual newspaper reports and the name of the newspaper are not disclosed in order to protect the anonymity discussed supra note 55 .

61. Merry, supra note 16 , at 67 .

62. Id.

63. See C. Harrington, supra note 51, at 158-59; Yngvesson, Legal Ideology and Community Justice in the Clerk's Office, 9 LEGAL STud. F. 71 (1985). 
lief: "You mean, because I used the wrong word?!. . . . You mean, nothing happens?" The clerk responded, saying that "[i]f I send this upstairs, they'll throw it out." The complainant left the court angrily. In a complaint brought by a woman against her neighbor for threatening her with a gun after the complainant's dog had attacked the neighbor's dog, the clerk refashioned the grievance as a matter for the dog officer to attend to and denied the application. ${ }^{65}$ In this way local stories of disorder are remade at the court by officials who define legal rights as relevant to the management of "serious" problems of order but who discourage using the court for handling "matters that might be considered 'minor' in the sense of the abstract legal issues presented and that involve essentially social, domestic and interpersonal conflicts."

In other courts, however, nuisance complaints become a basis for a collaboratively-invented legal culture in which local narratives are transformed into relatively flexible official categories; these categories, in turn, are stretched to accommodate local problems. The involvement of legal officials such as clerks or police is central, since their identities are shaped by extensive local ties as well as by their position at the court. Their local knowledge-of neighborhoods that "used to be quiet" before a business moved in, and of others in which threshers run all night; of which families local teenagers "run" from and of how this should be interpreted; or of how a conflict "about a driveway" is related to changing economic patterns in town- facilitates their participation in shaping tales as private nuisance or as public danger, and empowers complainants who use the courthouse to influence local ways of life. ${ }^{e z}$

Collective tales are not always so peacefully forged, however. Stories of disorder are more easily translated into a discourse of rights when the meanings of disorder are shared by complainants and court staff. Yet the heaviest users of many local courts are low-income populations, experienced with a range of public agencies, but viewed by police, court officers, social workers and others as leading inherently chaotic lives. The place of the court in the legal culture of this group facilitates the court's role as local "watchdog," but is incompatible with official representations of the court as an arena for "real" law. For low-income complainants, the courthouse becomes a forum in which alternative visions of community are played out, even as the lives of these complainants are defined as "chaos" and their grievances as "kidstuff" by court staff. These grievances-tales about violent Hispanic women, or about children who wield knives, tear

64. Yngvesson, supra note 63 , at 76-77.

65. Yngvesson, What is a Dispute About? The Political Interpretation of Social Control, in 2 Toward a General Theory of Social Control, supra note 24, at 236-37.

66. Massachusetts Committee of Juries of Six, Elimination of the Trial De Novo System in Criminal Cases 74 (1984).

67. The discussion in this and the following two paragraphs is based on material published in Yngvesson, supra note 6. 
each other's clothes, and start fires-become vehicles for neighborhood residents to keep out unwanted outsiders, but are framed in the language of crime at the court, in the discourse of child abuse for social agencies, and described as arson for the county housing office or the fire department. These matters tend to be dismissed by court officials, but complainants appear repeatedly with similar grievances, coming in groups to complain of "bad" neighborhoods and of indifference by local officials.

The appearance of these parties in court both challenges and strengthens the cultural framework through which their lives are officially explained. By using the courthouse as a forum to assert their right to a neighborhood free of violence, they resist the classification of disorder in their lives as normal trouble. By reenacting neighborhood battles in the courtrooms and hallways of the courthouse, they reaffirm official stereotypes that they are psychologically "irrational" and "brainless," and that fighting constitutes a "way of life" for them. The very enactment of these fights in a site that is set apart officially for "law" is perhaps the major form of popular resistance to a legal culture of rights to which this population has little access; at the same time, the use of local courts and of hearings by court clerks as arenas for these fights contributes to the official representation of forums such as these as "lower" courts from which "real" law is by definition excluded.

The persistence of some complainants in using criminal courts to shape community order in the face of unresponsive court officials can be contrasted with the determination of others to develop more effective alternatives for enforcing a moral order the court will not uphold. Recent examples of neighborhood vigilantism in combatting "crack houses" and other forms of local crime uncontrolled by the police and the courts are evidence of this determination. In 1988, two men in a working-class neighborhood in Detroit burned down a house where drugs were traded, with the support of local families, and were acquitted by a jury although they admitted to the burning. According to a news article describing the incident, one resident of this once quiet neighborhood said that "[n]obody could sit out on the front porch anymore. The kids couldn't play outside. The police said to wait till something bad happened. Well, we couldn't do that." The reporter stated that an expert described this act as "part of a larger pattern of citizen outrage and activism" that "expresses an extreme level of frustration with the perceived ability of police to handle violations of the law" in urban neighborhoods. ${ }^{68}$ These actions, which echo similar incidents in Manhattan, Miami, and elsewhere, suggest the potential politi5.

68. Wilkerson, 'Crack House' Fire: Justice or Vigilantism?, N.Y. Times, Oct. 22, 1988, at 1, col.

69. Id. at 1, col. 3 (quoting Dr. Mark H. Moore of Kennedy School of Government). 
cal importance of forms of legal action developed outside of, and in opposition to, the rule of law.

\section{Community Justice as Popular Gulture}

One of the most influential moves within the legal profession to shape legal culture in the United States is the alternative dispute resolution movement (ADR). Intended to displace the central role of the court for handling some conflicts while retaining the centrality of a professional elite, ADR is described by legal professionals and other advocates as a response to popular pressure for more participatory forms of conflict management, and as a shift away from a culture of unrestrained adversariness to one in which consensus is a more central value. Overcrowded and inaccessible courts are mentioned as part of the incentive for this shift, but it is also represented as a consequence of a "growing mood of antiprofessionalism" in the country and is described as a return to non-professional forms of community justice, familiar from the colonial period. ${ }^{70}$ Thus ADR is represented as a return to lay justice in response to popular demand.

There is little evidence that community justice is a popular movement, however. Most clients of neighborhood justice centers are referred there by the court, and those operated in complete separation from the court system have few customers. ${ }^{71}$ Nor is this clearly a movement administered by laypersons who represent local values and bring a local perspective. One of the dominant concerns in alternative centers throughout the country is training. In this process the choice of mediators is controlled, and the central symbols of alternative justice are defined in particular ways. ${ }^{72}$ Through a training procedure in which mediators with the closest community ties are eliminated, while educated professionals are favored, the meanings of "community" and of "consensus" are subtly redefined so that shared feelings, interpersonal communication and other core values of the helping professions become central in community mediation as well. ${ }^{73}$ The alternatives movement is extending a professional therapeutic culture in the guise of a popular culture developed from existing community values. $^{74}$

To illustrate how this affects the involvement of local communities in addressing problems of order, and the extent of local participation in constructing the meanings of central legal and cultural symbols such as "community," "neighborhood," and "rights," I draw on a recent study of a

70. See Dispute Resolution 3-4 (S. Goldberg, E. Green \& F. Sander eds. 1985); Sander, Varieties of Dispute Processing, in Neighborhood Justice 25 (R. Tomasic \& M. Feeley eds. 1982).

71. See C. Harrington, supra note 51, at 112; Harrington \& Merry, supra note 6, at 721.

72. Harrington and Merry, supra note 6.

73. Id. at 725-30.

74. Yngvesson, Disputing Alternatives: Settlement as Science and as Politics, 13 LAw \& Soc. INQUIRY 113, 130-31 (1988). 
mediation center in California. ${ }^{78}$ The study is unusual in that it examines the interactions of mediators with neighborhood residents, providing a detailed portrayal of how mediation centers produce "neighborhood justice" that complements studies of the way moral order is shaped in county courts.

The complaints handled by the mediation program, located in a major urban area in northern California, resemble those that are brought to criminal courts and are handled by clerks, police, prosecutors, and occasionally by judges. Principally neighbor and family conflicts, issues of race, ethnicity, gender, and class are central themes. ${ }^{76}$ In court, cases such as these are typically dismissed, although court staff may remain involved in them in various ways by "holding" them, issuing them "technically," or "continuing" them "to see if there is any more trouble." 77 Cases such as these are often described as "unresolvable" by court personnel, who have seen the same matters, involving the same or similar parties, go on for years. Mediation programs, by contrast, claim a high success rate with just these conflicts. ${ }^{78}$ The basis for this, mediation advocates claim, is in the active engagement of parties in resolving their own disputes. The third-party/mediator becomes a facilitator in this process, but control is located in the parties themselves. ${ }^{79}$ It is in this sense that alternative dispute resolution is seen as a move to more popular forms of justice, located in the neighborhoods where problems arise and controlled by the parties involved.

The issue of empowerment and of local control, linked in complex ways to the issue of "resolution," is central here. A number of earlier studies have questioned the extent to which the third-party in mediation simply "facilitates," and what "facilitation" means. ${ }^{80}$ Transformation theory fo-

75. J. Rothschild, Mediation as Social Control: A Study of Neighborhood Justice (1986) (unpublished Ph.D. dissertation, U.C. Berkeley). For a more general discussion of the goals of this program, see Shonholtz, The Citizen's Role in Justice: Building a Primary Justice and Prevention System at the Neighborhood Level, 494 ANNALS 42 (1987).

76. J. Rothschild, supra note 75 , at $88-111$.

77. "Technical" issuance is a strategy used by court staff to support the legitimacy of a complaint and sanction a defendant, without issuing a formal criminal charge. It is similar to "holding" a complaint, in that a formal criminal charge may be issued within a specified period of time (three to six months) if there is "any more trouble." See Yngvesson, supra note 6, at 435 n.33.

78. Merry, Defining "Success" in the Neighborhood Justice Movement, in NEIGHBORHOOD JusTICE, supra note 70, at 172.

79. See Folberg \& Taylor, Mediation, in Dispute Resolution, supra note 70, at 97; McEwen \& Maiman, Small Claims Mediation in Maine: An Empirical Assessment, in id. at 123; Sander, supra note 70 , at 28.

80. Yngvesson \& Mather, Courts, Moots, and the Disputing Process, in EMPIRICAL Theories ABOUT CouRTs 574-58 (1983). Yngvesson and Mather argue that mediators play a powerful role in shaping the course a conflict takes because of their control over the process of communication and because of their ties to other powerful groups in some communities. A recent study of divorce mediation in Great Britain provides evidence of the control by a mediator over the communication process, through a micro-analysis of conversation exchanges of the parties with the mediator. See R. Dingwall, Empowerment of Enforcement? Some Questions About Party Control in Divorce Mediation (paper presented at the Law and Society meetings, Washington, D.C., June 1987); see also Merry, The Social Organization of Mediation in NonIndustrial Societies: Implications for Informal Community 
cuses on the role of third parties in rephrasing conflict, so that the meaning of disputes may subtly shift, and mediators seem to be no less skilled in this process than third-party adjudicators. ${ }^{81}$ If, as Harrington and Merry argue, mediation programs systematically exclude neighborhood residents in favor of educated professionals, and these professional "volunteers" define and interpret the meaning of community and the nature of local conflict, then the extent of local control is questionable. At the same time, control and resistance may be evidenced in subtle ways, and this requires detailed examination of relations of power in mediation.

Rothschild's study of one of the best known community-based mediation programs ${ }^{82}$ suggests that while program ideology underscores local control (in the sense that citizens, rather than legal professionals, are handling neighborhood conflict), the practice of mediation systematically undermines the perspective and initiative of parties to a conflict. This is possible, in part, through the flexible use of symbols such as "neighborhood" and "local people," which are defined not by parties to a conflict, but by the center itself. For example, the program identifies six "neighborhood areas" within the same urban complex. These "neighborhoods" include populations ranging from 9,000 to 106,000 . While smaller subdivisions are recognized, even these cover quite extensive geographical areas and include populations of widely varying socioeconomic backgrounds. ${ }^{83}$ On this basis, volunteer mediators, who are required to live in these very general "neighborhood" areas, ${ }^{84}$ identify themselves as "local people," as "people like yourselves" who "care about the neighborhood and believe that neighbors can work together to solve local problems."8s Indeed, they are encouraged in the program training manual to identify themselves as "community members," although it is acknowledged that this term "has a specific meaning to volunteers, and a fairly ambiguous meaning to disputants." ${ }^{86}$ Yet the volunteers live on streets some miles distant from parties, may have to travel by freeway to reach the parties, and have backgrounds which differ notably from those of disputants. ${ }^{87}$

Justice in America, in The Politics of Informal Justice 17 (R. Abel ed. 1982). Merry argues that mediators in nonindustrial contexts derive power from their status as elders or members of local elites, and suggests that this role is distinct from that of mediators in neighborhood justice programs.

81. Mather \& Yngvesson, supra note 9, at 783-88. Mather and Yngvesson discuss the different ways in which the form or content of a conflict may shift as a result of the involvement of participants such as third parties, supporters, and others (for example, a community "audience" or "relevant public" of some kind). Forms of transformation include "narrowing," through which established categories for defining events and relationships are imposed on a conflict, and "expansion," in which new frameworks for classification emerge during the process of handling a conflict, reshaping the way events and relationships are defined. Id. at 783-97.

82. The program she studied is one of the few major neighborhood justice programs that operates separately from the court system.

83. J. Rothschild, supra note 75 , at $60-67$.

84. Id. at 180 n.7.

85. Id. at $78,79,149$.

86. Id. at $142-44$.

87. Id. at 179, 180; see also Harrington \& Merry, supra note 6, at 723-24. 
The practice of mediation as Rothschild describes it is oriented towards the empowerment of the mediators and at securing the dependence of parties on mediators. Mediators actively discourage efforts by participants to contact one another without the intervention of program volunteers. ${ }^{88}$ Further, mediators control the process by narrowing the number of potential participants, enhancing their own capacity to constrain the range of issues that might be raised, and how they are interpreted.

In one case, involving a middle-class black family in a conflict with white renters across the street, the "neighborhood" in question (in this case several spatially contiguous streets) had once been predominantly white, had gradually been occupied by black homeowners, and was now perceived (by the black family) as subject to pressure from white families moving in. In this case, the white family was operating a small business from their home, and this became the focus of the black family's complaint. Mediators chose to define this conflict as a communication problem between the two families, discouraged either of them from involving others, and focused the mediation session on a discussion of feelings rather than on the conflict of values and behaviors that seemed paramount to the parties themselves. In this way, mediators individualized what to the participants was a "community" problem, but did so in the guise of "community" empowerment. ${ }^{89}$

Both families in this case resisted the efforts of mediators to focus on communication and emotions. For example, one of the complainants, a middle-aged black man, responded to the volunteer's suggestion that a hearing should provide an opportunity for each side to learn about the feelings of the other by exclaiming: "I don't give a damn about his feelings. Wholely and solely I care that he be eliminated; not him, but his business." ${ }^{\text {"80 }}$ His concern, like that of established residents of the southern community studied by Greenhouse, the Midwesterners Engel writes of, and court users in a number of eastern cities and towns, was to prevent neighborhood change:

We moved here in 1947, because we wanted a quiet neighborhood. We've raised five children here. The neighborhood has been really important to us, and we don't want to see it change. If Paul [the defendant] is allowed to operate a business, then the next thing you know, every house will have a business, and it won't be a residential neighborhood any more. ${ }^{91}$

By contrast, the defendants, a white couple in their 30 's, were struggling to keep a family business going, and had been evicted from their

88. J. Rothschild, supra note 75 , at $149,155,156,163$.

89. Id. at $142-53 \& 301-04$.

90. Id. at 149 .

91. Id. at 190. 
previous home a few months earlier. When asked by the mediators about neighborhood values, the younger man replied: "I don't know what is important in a neighborhood. I never really thought about it."

Mediators in this case repeatedly sought to impose their definition of "neighborhood" and "community" (as a process of open communication about feelings) on the parties. For the black complainants, however, feelings could only be understood in the context of shared history and shared struggle. The wife in the black family responded to the mediators' efforts to have the parties share their feelings saying, "Paul [the defendant] could never understand my feelings-How could he? We had to fight to get here, we succeeded, we've been here since 1947 and we're not going to move now!!!"'s

By persisting in a definition of this conflict as a matter of failed communication, mediators undermined their capacity to work effectively with the parties. At the same time, the focus on communication (documented as a common settlement strategy in mediation centers throughout the country), ${ }^{94}$ framed it for all of the participants as a "private" matter, and undermined the potential for a more collective solution.

In evaluating the place of "neighborhood justice" programs such as this one in light of an ideology that underscores their capacity to create community in a cultural setting dominated by a concern with individual rights, it is revealing to compare the process described here with the management of an ethnically-based conflict at a local court in Massachusetts. There, while court staff also sought to narrow the conflict (in that case, to the verification of specific charges of assault, of threats, and of trespassing), they permitted large numbers of neighbors to appear and allowed a definition of issues that moved beyond a discourse of individual rights and of crime to issues of neighborhood order and the rights of economically depressed groups. Central to this stance by court staff were their own ties to the streets and the communities in which these problems emerged. Their lives, too, were affected by the economic and social conditions surrounding particular cases, and those involved were known to them. ${ }^{95}$ While this approach rarely resolved ongoing problems rooted in cultural difference and social inequality, and sometimes exacerbated these problems, it did not prevent collaborative action by residents of a neighborhood, and occasionally by neighborhood residents and court staff. Similarly, studies of colonial sessions courts suggest that the complex ties link-

92. Id. at 192 .

93. Id. at 202 .

94. Harrington \& Merry, supra note 6, at 725.

95. Yngvesson, supra note 6, at 432-33. Almost all the staff at the court (judges, clerks, probation officers and others) were residents of the town in which the court was located. The court clerk who handled many of the neighborhood conflicts brought to the court had been a local policeman for seventeen years before becoming a clerk, and thus knew many of the people and the places involved in these conflicts well. See id. at 417-19. 
ing paternalistic magistrates with the populations they governed created a basis for creative political action, however limited. By contrast, "neighborhood justice" is characterized by the cultural and social distance of mediators from those who come to them, and by an effort to construct cultural likeness (through the self-definition of mediators as "community members," "local people," etc.) without the structural basis for connection with local people.

It is not clear from existing studies of community mediation whether the kinds of popular pressure on local courts that facilitate use of these institutions in locally specific ways will also shape the ways alternative procedures are used. Most research relies heavily on interviews, and aside from Rothschild's study, the only work focusing on the "making" of mediation focuses on mediator training ${ }^{96}$ rather than on the interaction of mediators with local parties. Surely this interaction affects the forms and meanings of mediation and its place in the legal culture of this country. Yet the uneasy relation of "community" justice to existing neighborhoods and other social groupings, the tendency of some programs to identify "community" with trained professional mediators rather than with local cultural norms, and the self-conscious use of strategies that deflect collective concerns into "private" problems represent a powerful move to shape the perspective and values of local residents.

The legal culture produced through "neighborhood" justice appropriates the discourse of local identity while eclipsing local understandings of morality and justice. It effaces a history of shared experience-patterns of ethnic, sexual, and class inequality-in order to create new forms of interdependence between neighborhood residents and "neighborhood therapists," specialists in communications skills. These skills are put to use to frame conflicts in such a way that they require therapeutic intervention; indeed, as Rothschild's study suggests, complainants in neighborhood conflict are discouraged from attempting action on their own. By focusing on "private" feelings and their expression, justice also becomes a "private" matter, divorced from a structural context in which ongoing relations of inequality explain both the forms of conflict and of cooperation and the "private" feelings of individuals involved in these relations.

\section{Conclusion: The Production of Legal Gulture}

In this essay, I draw on studies of sessions courts in colonial New England and on ethnographic studies of legal practices and understandings in contemporary American communities to discuss legal culture as a contested terrain in which understandings of fundamental cultural symbols such as "community," "neighborhood" and "rights" are challenged and

96. Harrington and Merry, supra note 6. 
reinterpreted. While the roles of legal officials-judges, court clerks, lawyers, mediators in alternative dispute resolution programs, and others-are central in this process, I argue that the invention of law is not simply a one-way process, but that it emerges in the exchanges and the struggles of everyday people: in neighborhood fights and lovers' quarrels, in the framing of claims and complaints to police, the court, neighborhood justice and other agencies, and in the response of these agencies to such claims. The exchange is clearly an unequal one, most apparent in the control exercised by court officials and others through their knowledge of legal and therapeutic discourse, and their authority as experts to use this knowledge to label the behavior of others. ${ }^{97}$ Problems defined by middleand working-class court users as matters of "rights" may be transformed into "nuisance" problems by the court, but efforts to use the court to shape local problems of disorder may also be supported in various ways by officials whose practice depends upon interaction with local people, and whose legitimacy is based in part on local knowledge. For poor complainants, the use of the court to shape moral order is more of a struggle, and even the most organized acts of resistance to professional labelling are typically reinterpreted as "chaos" by experts.

For all of these groups, current moves within the legal profession to redirect family and neighborhood problems into mediation programs may have a long-range effect on the way the court is used and on its cultural place, while extending the capacity of professionals of various kinds to control the meanings of disorder in families and neighborhoods, the nature of claims and where they can be handled, and the definition of "community" as a form of participation in disputing, rather than as local understandings about morality. In this way, the "popular" in legal culture may become increasingly professionalized, while people who have grown disillusioned with the court and find "community justice" irrelevant to their concerns may seek other forms of alternative justice for handling what they interpret as intolerable disorder in their lives.

97. See J. Donzelot, The Policing of Families (1979). 
